\title{
Comparative Assessment of the Changing Morphometry of River Dhalai \& Land use Pattern of Kamalpur Town and Halhuli Village, Tripura, India
}

\author{
Srijib Basak ${ }^{1}$, Saswati Rudrapal ${ }^{2}$ \\ ${ }^{1}$ Assistant Teacher, K.B.M.S. Simna, West Tripura, Tripura -799212, India \\ ${ }^{2}$ Department of Geography and Disaster Management, Tripura University, Suryamaninagar, Tripura - 799022, India
}

\begin{abstract}
The research work is an attempt to analyse from both perspective of geography viz. the physical portion where we determine the channel pattern and measuring the shifting course of Dhalai river as well as in the social portion where we compare the changing land use pattern of last few decades through 16 cross section of Kamalpur town and Halhuli Village. The study area is situated in the extreme northern part of Dhalai District and also the state of Tripura. For assessment of the morphometric change mainly the channel pattern and channel shifting, we used Sinuosity index, Braiding Index and also calculate the percentage of area had already being shifted from 1970 to 2015. On the other hand, the changing land use pattern along the river had been analysed by creating diagram based on some cross section and represent the relation of land use pattern with the elevation. The result of this research is positively related to each other from its both perspectives. Basically the entire research work is based on secondary source of data from different sectors and Google earth along with door to door survey, GPRS reading and selection of study area through ground observation.
\end{abstract}

Keywords: Dhalai River, Shifting of River, Sinuosity index \& Braiding Index, land use pattern and its relation with elevation, RuralUrban travel behaviour.

\section{Introduction}

Rivers are dynamic geomorphological agents showing great deal of diversity in form and behaviour and also in transfer of water and sediment load from land surface to the oceans [1]. Alluvial course are very sensitive indicators of channel change and can read to just variation in Hydrology, sediment load and active tectonics. Lateral shifting is a type of change of immense importance which can be detected by its asymmetric position in the river valley and the evidences of its spatio-temporal shift in one direction [2]. On the other side, the study of land use pattern is very essential to know the relationship between man and natural environment [3]. The term land use relates to the human activities associated with specific piece of land, factures present on the earth surface [4]. Land use involves the management and modification of natural environment or wilderness into built environment such as settlements and semi-natural habitats such as arable fields, pastures, and managed woods. [5]

Human civilization may build over a place based on the physical condition as well as the social perspective of that place and it's continue upgraded with the positive utilization of these two perception. River is a source of unlimited resource by which a civilization may easily build in any place throughout the world. But the other factors are like soil quality, presence of Vegetation, agricultural field, transport and communication systems are also a very effective factors now a days.

The first part of this paper discusses about the channel pattern and shifting course of Dhalai river whereas in the second part the comparative study of land use pattern from 1970 to 2015 has been presented through some cross section. Hence, this is an attempt from both the perspective of geography.

\section{Objective}

1) Detection the "Channel pattern" and measurement of "Shifting of Dhalai River" from 1970 to 2015, within the study area.

2) Comparative analysis of land use pattern from 1970 to 2015 through different cross-section and weigh up the major changes.

\section{Regional Background of the Study Area}

The selected study area incorporated one town (Kamalpur) and one village (Halhuli) of Durga Chowmohuni block, under Kamalpur sub-division of Dhalai district along the river Dhalai. The river Dhalai takes its rise from the Dolajari peak of Longtarai Range and runs towards north in a meandering course through Kamalpur town of Dhalai district. The study area covered only $0.919 \mathrm{sq} \mathrm{km}$ area and $2.30 \mathrm{~km}$ length of river Dhalai. The study area is mainly composed of sandstone, silt stone, alluvium and shale like its entire course. Altitude variation of the basin and its surrounding area ranges between $32 \mathrm{~m}$ to $42 \mathrm{~m}$ (Fig. 1). Climatically the area falls under hot and humid summer and a long-standing rainy season with warm winter. The maximum and minimum temperature of summers and winters are $37 \mathrm{c}, 17 \mathrm{c}$ and $28^{\circ} \mathrm{c}, 5.3^{\circ} \mathrm{c}$ respectively [6]. In case of relief feature most of the places are covered by undulating topography which is regionally known as "Tilla \& Lunga", which is a result of strong tectonic activity in Tertiary and Quaternary Periods.

The District headquarter Ambassa is located at a distance of about $37 \mathrm{~km}$ from the study area and it is connected through Ambassa-Kamalpur Road . Mainly the area is covered by Tripuri, Reang and Kuki tribes . The study area is exactly located between $24^{\circ} 11^{\prime}, 06^{\prime \prime} \mathrm{N}$ to $24^{\circ} 12^{\prime} 00^{\prime \prime} \mathrm{N}$ latitude and $91^{\circ}$ $49^{\prime} 25^{\prime \prime} \mathrm{E}$ to $91^{\circ} 50^{\prime} 37^{\prime \prime} \mathrm{E}$ longitude. The river Dhalai is the 


\section{International Journal of Science and Research (IJSR) ISSN (Online): 2319-7064}

Index Copernicus Value (2013): 6.14 | Impact Factor (2015): 6.391

main river of Dhalai District and kamalpur town is one of the Sub-division of this district.

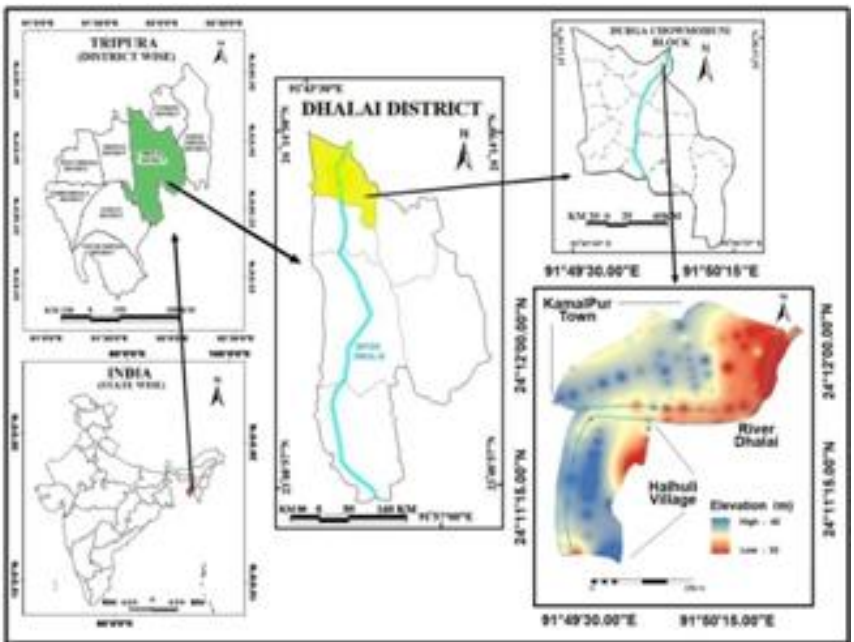

Figure 1: Location of the study area with Elevation Model (EM)

\section{Materials and Methods}

For the present research work, first of all, the selection of study area had been done along some literature reassess. Based on this two pre-field work digitization of the study area and door to door survey had been done within a same time. Then we geo-referenced the digitized map into Universal Transverse Mercator (UTM) to make Elevation map, changing channel pattern map and land use map with the help of Arc GIS 9.3 and Global Mapper 8. Based on our two objectives we used Sinuosity Index (S.I.), Braiding Index (B.I.) to detection the Channel pattern and shifting course. And to compare the changing land use pattern of different years, 16 diagrams ( 4 from each year) had been drawn along the same interval with the help of some cross section. Diagrams were prepared in Arc GIS where we easily prepared the structure of topography from the contour map and then digitized the land use pattern with respect of that topography. Last but not the least analysis of the whole research work is based on both primary and secondary survey and try to deliver some suitable future scope mainly based on door to door survey that the local people faced in their daily life.

Table 1: Methods of Data analysis:

\begin{tabular}{|c|c|c|c|}
\hline No & Indices & Formula & Remarks \\
\hline \multirow{3}{*}{1} & \multirow{3}{*}{$\begin{array}{l}\text { Sinuosity Index } \\
\text { (S.I.) (Leopold \& } \\
\text { Miller, 1964) }\end{array}$} & \multirow{3}{*}{$\begin{array}{c}\text { S.I. }= \\
\mathbf{L}_{\mathrm{cmax}} / \mathbf{L}_{\mathbf{R}}\end{array}$} & $>1.5=$ Meandering Channel \\
\hline & & & $1.50-1.00=$ Sinuous Channel \\
\hline & & & $<1.00=$ Straight Channel \\
\hline 2 & $\begin{array}{c}\text { Braiding Index } \\
\text { (B.I.) }(\text { Brice, 1964) }\end{array}$ & $\begin{array}{c}\text { B.I.= } \\
2 \sum_{\mathbf{L b}} / \mathrm{I} \\
\mathbf{L m}\end{array}$ & $>1.5=$ Braiding Pattern \\
\hline
\end{tabular}

$\mathbf{L}_{\mathbf{c m a x}}=$ mid channel length, $\mathbf{L}_{\mathbf{R}}=$ Straight length

$2 \sum \mathbf{L b}=$ Sum of the length of islands $/$ bars, $\mathbf{L m}=$ length of the reach.

\section{Reassess of Literature}

Leopold \& Wolman, 1957 first invented the measurement of channel pattern and classify it also. Bandyopadhyay, $\mathbf{S}$ et al 2013 used the Bank Erosion and Hazard Index (BEHI) model to measure how much area had been shifted within 2 to 3 years and identify the process and causes by which the bank eroded of Haora river, West Tripura. Friend P.F. et al 1993 used the technique of Sinuosity Index and Braiding Index for detection the channel pattern and identification of shifting course of river. The same methodology had been followed by Laha C et al $\mathbf{2 0 1 3}$ for Analysis of the Changing Morphometry of River Ganga. A comparison work of about 35 years changing course of Pravara River had been done by Aher S.P et al 2012 based on Topographical Map and RS \& GIS technique. They are generally tried to show the changing phase of river along with its flood condition, water velocity, sand excavation, removal the vegetation cover and fertile soil excavation for the various proposes of local peoples.

According to Iqbal, $\boldsymbol{M}$. $\boldsymbol{e t}$. al.201, proper land use planning and policies is essential for a sustainable development because of sudden decrease in agricultural area, forest \& vegetation and tremendous increase in settlement can be create many harmful effect on that environment (Kotoky,P.et.al. 2012). On the other side Land use / land cover is an important component in understanding the interactions of the human activities with the environment and through empirical observation these changes are easily identified (Gajbhiye. S. \& Sharma.S.K.2012).

\section{Result and Discussion}

\section{Assessment of Morphmetrical Changes in Dhalai River} with Different Time Period:

Channel pattern is used to describe the plan view of a reach of river as seen from an aeroplane, and includes meanderings, braiding, or relatively straight channel [6]. The river forms reflect three main independent factors, namely (A) the discharge regime which depends on climatic and soil conditions; (B) the slope or gradient conditioned by the relief of the area crossed by the river; $(\mathrm{C})$ the erodibility of the bed depending on the sediment properties. These three controls determine features of the river pattern and hydraulic conditions of the flow [7]. The main implication of channel pattern is to identify that the river fall in which stage of cycle of erosion and what its future movement in which direction and by this we can easily suggest the suitable site selection of build up the settlement and also the transportation facility.

The Braiding index of a river is depending on the length of islands and bars are present in that river. And the degree of braiding can be expressed by the percentage of reach length that is divided by one or more islands or bars [8]. The length of islands and bars are depends upon the stage at which they are measured [9]. The percentage of bars and islands depend on the erosional and transportasional work of that river in its youth and mature stage respectively.

\section{A. Year 1970; Dhalai River Reach:-}

Here the river reach has been digitized from the Google Earth of $11^{\text {th }}$ March, 1970. The channel indicated slightly meandering pattern with the value 1.51 . Almost $12.91 \%$ area was under the Island area in respective of total river basin and the value of braiding was low. The measured B.I. is 


\section{International Journal of Science and Research (IJSR) \\ ISSN (Online): 2319-7064}

Index Copernicus Value (2013): 6.14 | Impact Factor (2015): 6.391

0.87. The trend of shifting of river was quite slow at that time.

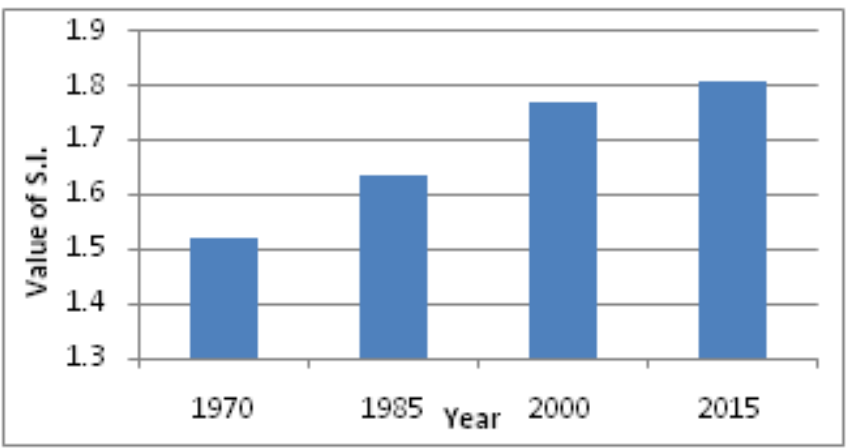

Dig: 1, Value of S.I. year wise.

B. Year 1985; Dhalai River Reach:-

Here the river reach has been digitized from the Google Earth of $16^{\text {th }}$ March, 1985. Here river started shifting towards West, North- west and South- Eastern part. Only $0.0325 \mathrm{Km}^{2}$ areas had been shifted from 1970 to 1985 . The sinuosity index of the river was 1.63 and it's clearly indication for a meandering pattern. From 1970s, the sinuosity has increased 0.12 . Almost $14.94 \%$ island area in this year has been increased and reaches $27.85 \%$ in respective of the total river area. So it's the year when there was an extreme change in the island area. The B.I. value was 1.49 and it also increased with the increasing of island. Due to the sudden increase of sedimentation, the river started lateral erosion and enlarged its width.

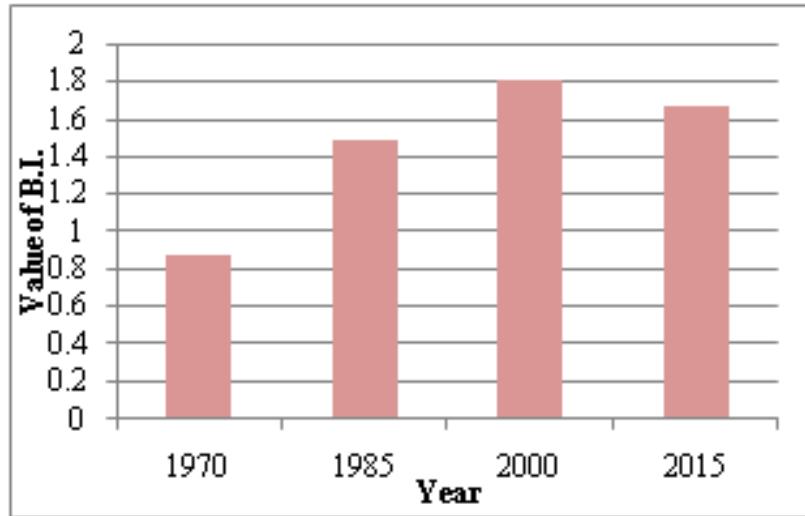

Dig: 2, Value of B.I. year wise

\section{Year 2000; Dhalai River Reach:}

Here the river reach has been digitized from the Google Earth of $05^{\text {th }}$ March, 2000. Almost $0.0537 \mathrm{Km}^{2}$ areas had been shifted with in 15 year and it shifted towards North, North-West and South-Eastern part of this river. There was a massive change found in S.I. value from 1985. The value of S.I. was 1.77 and it increased approximately 0.14. A slight $0.54 \%$ increase had been found in island area in respect of 1985 and reaches $28.39 \%$ in respective of the total river area. The B.I. value was 1.80 and it increased almost 0.31 from 1985 with the increasing of island.

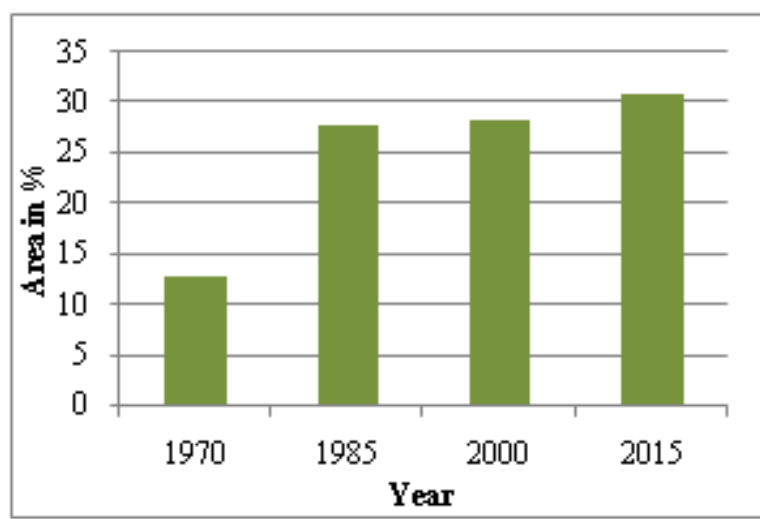

Dig: 3, Islands or bars area year wise.

\section{Year 2015; Dhalai River Reach}

Here the river reach has been digitized from the Google Earth of $05^{\text {th }}$ April, 2015. Approximately $0.0023 \mathrm{~km}^{2}$ and $0.0598 \mathrm{~km}^{2}$ areas had been shifted towards North- West and South- Eastern part respectively. In the year 2005 the growth of settlement had been increased in the left bank of Dhalai river and for the survival of the local people retaining wall (mixed of bolder and big stone) may built by the local government. And due to this the shifting of Dhalai river in its left bank was totally stopped after 2005. Almost 0.0084 $\mathrm{Km}^{2}$ areas had been shifted from 2000 to 2015. The sinuosity index of the river was 1.81. From 2000s, the sinuosity has increased 0.03 . Almost $2.44 \%$ island area in this year has been increased and reached $30.83 \%$ in respective of the total river area. The B.I. value was 1.66 and it decreased from 2000 with a value of 0.12 . The reason behind this is sudden increase of settlement in Kamalpur Town. And most of them are used the river sand as a particle to build their house and also used the sand as commercial purpose.

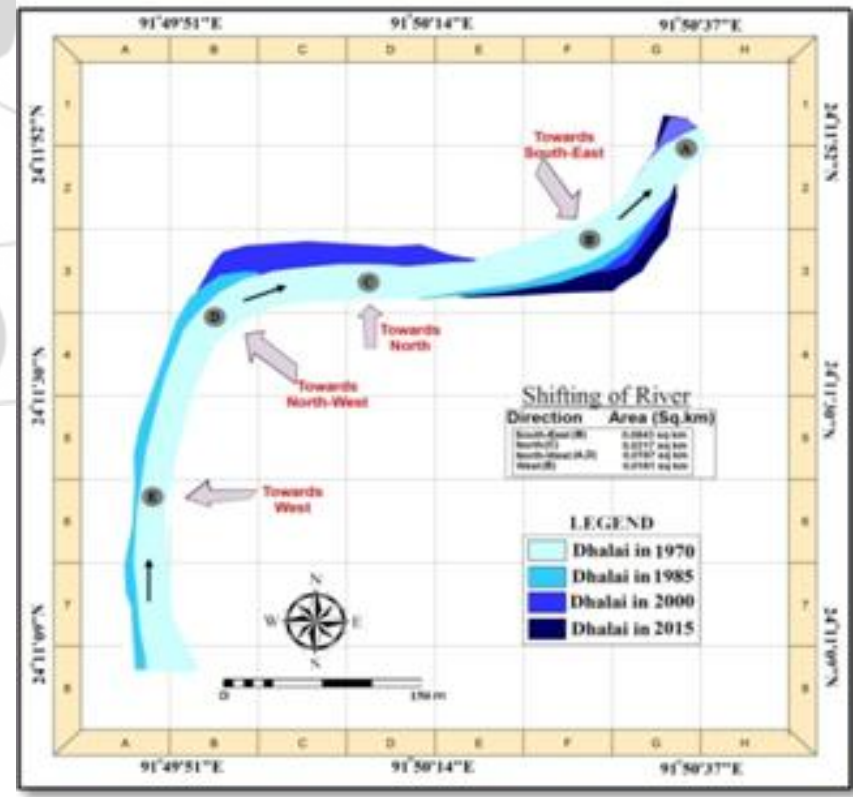

Figure 2: Channel pattern and changing course of Dhalai River through time (Google Earth \& Arc GIS)

Comparative Assessment of changing Land use Pattern from 1970 - 2015:

Land use and land cover (LULC) change is a major issue of global environmental change and therefore LULC mapping is essential component where in other parameters are 


\section{International Journal of Science and Research (IJSR) \\ ISSN (Online): 2319-7064}

Index Copernicus Value (2013): 6.14 | Impact Factor (2015): 6.391

integrated on the requirement basis to drive various developmental index for land resource management. The land cover reflects the biophysical state of the earth's surface and immediate subsurface, thus embracing the soil material, vegetation, and water [10].

Land use is a more complicated term; it has been defined in terms of syndromes of human activities such as agriculture, forestry and building construction that alter land surface processes including biogeochemistry, hydrology and biodiversity. Accelerated conversion of forest land, due to rapid urbanization and other allied activities like intensive agricultural practices, overexploitation of resources and other anthropogenic activities have resulted to changes in land-use and land cover pattern. Significant land-use/land cover changes have been reported during the last century both on spatial and temporal scale, mainly due to economic development and population growth [11] Anthropogenic changes in land use and land cover are being increasingly recognized as a critical factors influencing global land use change [12].

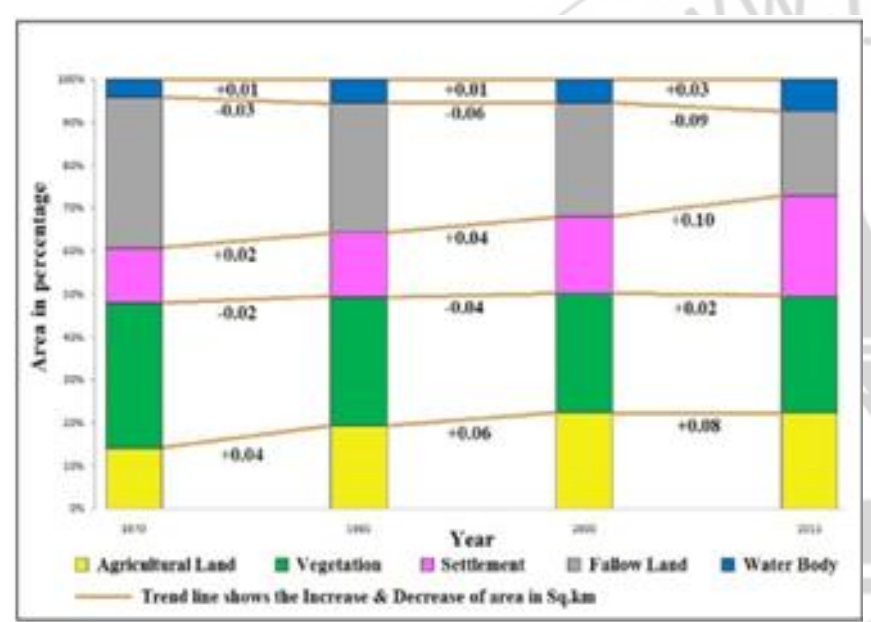

Dig: 4, Year wise Land use pattern with Trend line. (Primary Survey and Google Earth)

The study area is mainly cover up with five types of land use pattern viz. Agricultural land, vegetation cover, settlement, fallow land and water body. In the year 1970 the percentage of settlement area was very low and due to this reason most of the land was covered with fallow land and vegetation. Whereas the percentage of agricultural land and water body was also low due to absence of people. But in the year 1985 the percentage of settlement was increased by $0.02 \mathrm{Sq} . \mathrm{km}$ and with it agriculture land and water body was also increased by 0.04 and $0.01 \mathrm{Sq} . \mathrm{km}$ respectively. Beside this vegetation cover and fallow land become decrease by 0.02 and 0.03 Sq.km. The condition of transport and communication system of that time was very poor. There is only a bridge between kamalpurpur and halhuli which was made by bamboo. In the year 2000, the condition was much better than the previous years. Settlement area was increased by $0.04 \mathrm{Sq} . \mathrm{km}$ along with agricultural land and water body and on the other side the area of fallow land and vegetation cover was decreased by 0.04 and 0.06 Sq. km. Mainly this is the time period where the process of urbanization may start in Kamalpur town, whereas the condition of Halhuli village was very critical at that time. In 2015, the growth of settlement pattern was tremendous and it's increased by 0.10
Sq. $\mathrm{km}$ in respect of 2000. With the increasing demand of food facility the area of agricultural land and water body was also increased by 0.08 and $0.03 \mathrm{Sq} . \mathrm{km}$. The area of fallow land was sudden decrease by $0.09 \mathrm{Sq} . \mathrm{km}$ due to increasing pressure of settlement. At this stage the condition of transport and communication system was much better than the previous years. The only bridge was now converted from bamboo to Cemented. Most of the roads were covered up with black top. The condition of Halhuli village was much better than the previous years because of well connected transportation system with the sub- division Kamalpur town where they got almost each and every facility in their day to day life. And because of those facilities "Rural-Urban travel behaviour" [13] had been found in this place.

\section{Analysis the Relationship of Land use Pattern through}

\section{Elevation:}

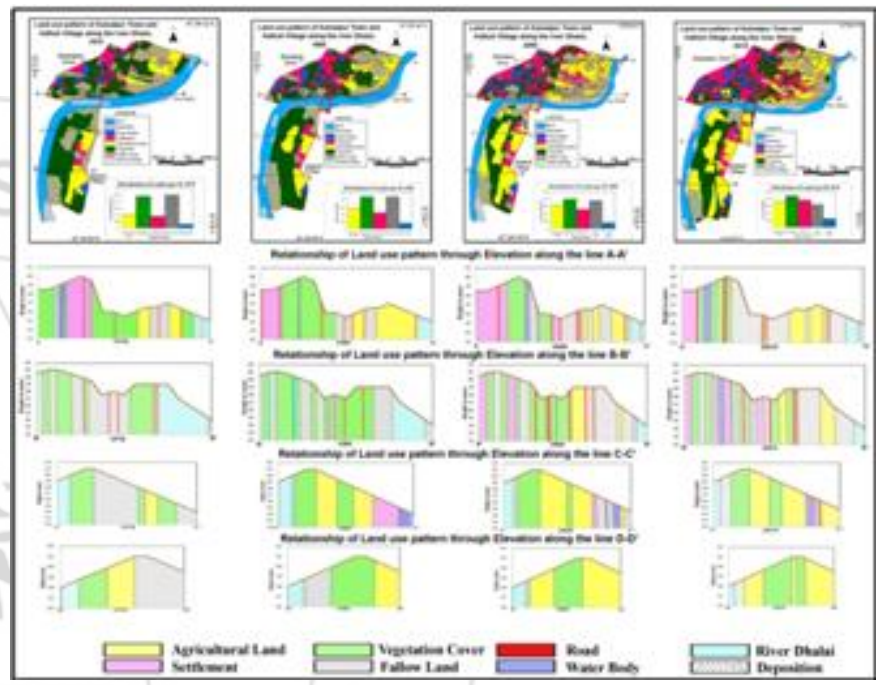

Figure 3: Land use map and its relation through elevation along some cross section. (Google Earth, Global Mapper \& Arc GIS)

As we know, most of the places of Tripura are covered by undulating topography which is regionally known as Tilla (Convex) \& Lunga (Concave). Fig. 3, represent the changing relation between land use pattern and elevation factor based on some cross section in the study area.

- In case of cross section A-A' (based on Kamalpur Town), settlement may build up at the highest elevation only in 1970 at $41 \mathrm{~m}$. whereas 1985, 2000 and 29015 it shifted to below $39 \mathrm{~m}$. due to increasing growth of transportation system. All the settlement was situated very far from the river due to its bank erosion. On the other side agricultural field and water body may found at 34 to $35 \mathrm{~m}$. and over $38 \mathrm{~m}$. height respectively. The agricultural land situated very far from the inside water body and very close to the river Dhalai which clearly indicate that the local people main used the water of river for agricultural activity. The vegetation cover and fallow land may found in high elevation and it getting decrease due to the population pressure and developed transportation system. At the lowest altitude river Dhalai is situated with its deposition feature.

- In case of section B-B' (based on Kamalpur Town), $80 \%$ area was covered under vegetation and fallow land with the elevation of $40 \mathrm{~m}$. in 1970 and 1985 with low facility of transportation system. But with the increasing of time, 


\section{International Journal of Science and Research (IJSR) \\ ISSN (Online): 2319-7064}

Index Copernicus Value (2013): 6.14 | Impact Factor (2015): 6.391

in 2000 population pressure may arise and at a height of $40 \mathrm{~m}$. settlement may build up. Along this settlement agricultural land and water body may also increase with a height of $35 \mathrm{~m}$ and $39 \mathrm{~m}$ respectively. In 2015 settlement was build up in everywhere like $40.5 \mathrm{~m}, 39 \mathrm{~m}, 35 \mathrm{~m}$ etc. along with developed transport and communication system. Vegetation cover and fallow lands are situated dispersedly here and there with an elevation of $35 \mathrm{~m}$. to 40 $\mathrm{m}$. The trend of building up the settlement was very far from the river like the section A-A' due to the bank erosion.

- In case of section C-C' (based on Halahuli Village), the tradition of building up of settlement in respect of Kamalpur town was quite opposite. Most of the settlement may build up $35 \mathrm{~m}$. or below it. In 1970, most of the high lands were covered by fallow lands and vegetation covers whereas the river was situated almost $39 \mathrm{~m}$. height. But in 1985 and 2000 year, due present of settlement most of the fallow land was converted to agricultural land and it was found at a height of $40 \mathrm{~m}$. to $37 \mathrm{~m}$. in 1985 and $40 \mathrm{~m}$. to $35 \mathrm{~m}$. in 2000. Most of the agricultural land was found in between river and inland water body which is a clearly indication of uses of both water for agriculture. But in 2015 most of the settlement was build up at a height of 36 $\mathrm{m}$. and beside of water body. That means the local people use the water for their daily use as well as commercial purpose. Whereas at $40 \mathrm{~m}$. height most of the vegetation cover and fallow land was tried to clear and converted it into agricultural land. The average elevation in this cross section of river was $39 \mathrm{~m}$.

- In case of section D-D' (based on Halahuli Village), at an elevation of $41 \mathrm{~m}$. fallow land had been found in 1970 along some vegetation cover $(38 \mathrm{~m}$.) and very little amount of agriculture land $(40 \mathrm{~m}$.) due to lack of settlement. But in 1985, 2000 and 2015 due to increase of settlement most of the places at an elevation of $36 \mathrm{~m}$. to $41 \mathrm{~m}$. were covered by agricultural land. And the amount getting increase with increasing of time. And fallow land was totally missing at this stage where as a little amount of deposition was found on $38 \mathrm{~m}$. elevation.

\section{Future Scope}

1) Presently the river channel is going through under Irregular meandering course whereas in future there will be a probability to change it into a Tortuous meandering channel pattern.

2) Due to build up of Kamalpur town in the left bank of the river the shifting is totally stopped but it continues shifting in its right bank (south-eastern) with an average $0.045 \mathrm{Sq} . \mathrm{km}$ per year.

3) Increasing growth of population in Kamalpur town with others modern facility clearly indicates that within 5 to 10 years it will come under municipality.

4) In the view point of land use planning or proper land use pattern, the future development will be quite satisfactory. Because of people are trying to build up their settlement in relatively flat land in respective of Tilla \& Lunga. And they used Tilla \& Lunga either for rubber or bamboo plantation or production of food.

5) There will be a probability to start the broad gauge train line within May, 2016. That will definitely develop the whole area from the all perspective by not only connected within the state but also the whole India.

\section{Conclusion}

From the above discursion we are clearly articulate that the channel pattern is "Meandering". The value of S.I. become increase year by year that indicate "Tortuous meandering" course in future. But at present the structure and the shape of the meanders are not similar through out of its course that is the characteristic feature of "Irregular meandering". And this kind of channel pattern is very common along the longitudinal course of alluvial rivers where pools and point bars are found. On the other hand, the river is going through the "Mature stage" of Cycle of erosion which clearly indicates that the river lost its eroded power and the main work of the river is deposition.

The land use planning of the study area was quite developed as the increasing settlement may build up far behind from the river. Most of the area near river is occupied by either fallow land or agricultural land. And the main source of water for agriculture is the water of river Dhalai. Last but not the least, river Dhalai left a positive economic impact over Kamalpur Town and Halhuli village.

\section{References}

[1] Mallick, S. (2014) Identification of FluvioGeomorphological Changes and Bank Line Shifting of River Bhagirathi-Hugli Using Remote Sensing Technique in and Around of Mayapur Nabadwip Area, West Bengal

[2] Schumm, S. A., Schumm, S. A., Dumont, J. F., \& Holbrook, J. M. (2002).Active tectonics and alluvial rivers. Cambridge University Press

[3] Tripathi R.S, and Vishwakarma J.P.-(1988), 'Landuse cropping pattern and development levels in Banda district (U.P.)'. The Deccan Geographer vol.XXVI No.2-3 pp 417-27

[4] Lillesand, T, M. and Kiefer R.W. (1987). 'Remote sensing and Image Interpretation' John Wiley and Sons, $\mathrm{p}-74$

[5] https://en.wikipedia.org/wiki/Land_use

[6] Dhalai District Profile, 2015

[7] Wolman, M. G., \& Leopold, L. B. (1957). River flood plains; some observations on their formation (No. 282C)

[8] Lokhtin, V. M. (1897). About a mechanism of river channel. Voprosy gidrotekhniki svobodnykh rek, 23-59

[9] Chorley, R. J., Schumm, S. A., \& Sugden, D. E. (1985). Geomorphology, 605 pp. Methuen, London

[10] Morisawa, M. (1985). Rivers: form and process. K. M. Clayton (Ed.). London: Longman

[11] Turner T. J, George I.M., Snowden S.L, Yusaf R and Hasinger G., (1995), Calibration corrections applied to individual PSPC events", MPE/OGIP Calibration memo CAL/ROS/95-010, NASA, Goddard Space Flight Center, Greenbelt, MD 20771

[12] Mitch G., (1993), Landscape ecological planning through a multi-scale characterization of pattern: 


\section{International Journal of Science and Research (IJSR) \\ ISSN (Online): 2319-7064}

Index Copernicus Value (2013): 6.14 | Impact Factor (2015): 6.391

studies in Western Ghats, South India, Environment monitoring Assessment, pp 215-233

[13] Nagendra, H., Munroe, D. K., \& Southworth, J. (2004). From pattern to process: landscape fragmentation and the analysis of land use/land cover change. Agriculture, Ecosystems \& Environment, 101(2), 111-115

[14] Ramachandran, R. (1989). Urbanization and Urban Systems in India: Their Origins Under the Impact of the British Colonial Policy. Stockholm: SAREC.

[15] Bandyopadhyay, S., Saha, S., Ghosh, K., \& De, S. K. (2013). Validation of BEHI Model through Field Generated Data for Assessing Bank Erosion along the River Haora, West Tripura, India. Earth Science India, 6(3)

[16] Friend, P. F., \& Sinha, R. (1993). Braiding and meandering parameters.Geological Society, London, Special Publications, 75(1), 105-111

[17] Laha, C., \& Bandyapadhyay, S. (2013). Analysis of the Changing Morphometry of River Ganga, shift monitoring and Vulnerability Analysis using SpaceBorne Techniques: A Statistical Approach. International Journal of Scientific and Research Publications, 3(7)

[18] Aher, S. P., Bairagi, S. I., Deshmukh, P. P., \& Gaikwad, R. D. (2012). River change detection and bank erosion identification using topographical and Remote Sensing Data. Inter. J. App. Infor. Sys, 2(3), 17

[19] Iqbal, M., Rashid, S. M., Sajjad, H., Siddiqui, M. A., \& Siddiqui, L. (2012). Anthropogenic impact on Landuse/Landcover in Dudhganga Watershed of Kashmir Valley, India. International Journal of Geomatics and Geosciences,2(3), 902

[20] Kotoky, P., Dutta, M. K., \& Borah, G. C. (2012). Changes in landuse and landcover along the Dhansiri River channel, Assam-A remote sensing and GIS approach. Journal of the Geological Society of India, 79(1), 61-68

[21] Gajbhiye, S., \& Sharma, S. K. (2012). Land Use and Land Cover change detection of Indra river watershed through Remote Sensing using Multi-Temporal satellite data. International Journal of Geomatics and Geosciences, 3(1), 89

[22] Ghosh, K., De, S. K., Bandyopadhyay, S., \& Saha, S. (2013). Assessment of soil loss of the Dhalai river basin, Tripura, India using USLE

[23] Das, B., Mondal, M., \& Das, A. (2012). Monitoring of bank line erosion of River Ganga, Malda District, and West Bengal: Using RS and GIS compiled with statistical techniques. Int J Geomat Geosci, 3(1)

[24] Das, S., Adak, K., \& Samanta, K. (2014). Hydrodynamic changes of river course of part of Bhagirathi-Hugli in Nadia district-A Geoinformatics appraisal. International Journal of Geomatics and Geosciences, 5(2), 284-299

[25] Mandal, R. B. (1990). Land utilization: Theory and practice. Concept Publishing Company.

[26] Mongaldip, M., Pintu, P., \& Kumar, B. N. (2015). Bank Erosion and Shifting Nature of the Hooghly River at Sundalpurchar and Gosainchar Mouza, Ranaghat-I Block, Nadia District, West Bengal,
India. European Journal of Academic Essays, 2(7), 8386

[27] Raj, R., Mulchandani, N., Bhandari, S., Maurya, D. M., \& Chamyal, L. S. (2004). Channel shifting of a highly sinuous meandering river in alluvial plain, Vishwamitri river, Mainland Gujarat. Current Science, 86(12), 1647-169

[28] Brief Industrial Profile of Dhalai District, created by Development Institute Adviser Chowmohani Krishnanagar Road, Agartala 799001, Tripura.

\section{Author Profile}

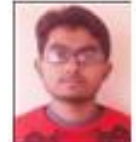

Srijib Basak is an Asst. Teacher of KathiaBaba Mission School (T.P.S.E. Affiliated), Tripura. He has completed his M.A. from Tripura University (A Central University) in the academic year 2012-2014.

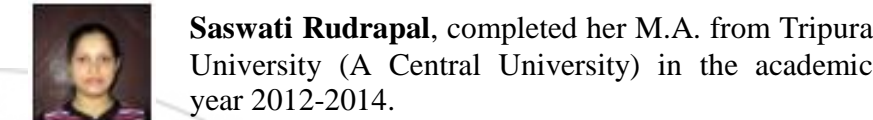
year 2012-2014. 